\title{
BENEFITS OF INTEGRATED FARMING SYSTEM FOR CATTLE CROPS IN NORTH BOLAANG MONGONDOW REGENCY NORTH SULAWESI PROVINCE, INDONESIA
}

\author{
Femi Hadidjah Elly ${ }^{1}$, Agustinus Lomboan ${ }^{1}$, Charles L. Kaunang ${ }^{1}$ and R. Pomolango ${ }^{2}$ \\ ${ }^{1}$ Faculty of Animal Husbandry, University of Sam Ratulangi, Manado, North Sulawesi, Indonesia \\ ${ }^{2}$ Faculty of Agriculture, University of Muhammadiyah, Gorontalo, Indonesia \\ http://doi.org/10.35410/IJAEB.2019.4401
}

\begin{abstract}
The potential of cattle farming in North Bolaang Mongondow Regency is sufficient. The data show that the cattle population amounts to 14690 heads (2015), and the population increases from 2013 to 2015 by $6.93 \%$. The government is trying to increase the population so that various programs have been launched in this area. On the other hand the increase in population gives consequences of increased cattle waste. Cattle farming is considered as one of the causes of $\mathrm{CO} 2$ emissions which lead to increased global warming. Efforts that can be made to minimize greenhouse gas emission increase is by integrated farming system of cow-plant. The problem is whether the integration of cattle-crop farming benefits cattle farmers. The purpose of this research was to analyze the benefits of farming of cattle-crop integration. The research method used was survey method. The location of the research was the district that has the largest population of cattle, namely District of Sangkub and Bintauna determined by purposive sampling. The results showed that cattle farming integrated with food crops has been done by several farmer groups. Cattle were kept by using cages and the feed used was waste of rice and corn. Cattle manure has been made of solid fertilizer, and liquid fertilizer. Liquid fertilizer produced was 25 liters/day sold at $\mathrm{Rp} 30000 /$ liter, solid fertilizer as much as $10000 \mathrm{~kg} /$ year, the price of Rp 1000/kg. Based on the result of the research, it can be concluded that integrated farming system, cattle-crop farming provides positive benefits for farmers in increasing income

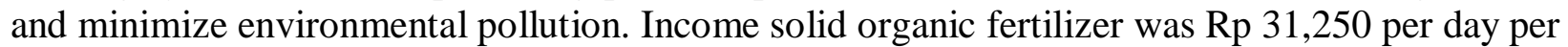
head. Suggestions submitted need socialization and assistance in the development of integrated cattle farming.
\end{abstract}

Keywords: Integration, cattle, crops, benefits

\section{INTRODUCTION}

The potential of cattle farming in Regency of North Bolaang Mongondow is sufficient. The data show that the cattle population amounts to 14690 heads (2015), and the population increases from 2013 to 2015 by $6.93 \%$. The government is trying to increase the population so that various programs have been launched in this area. On the other hand the increase in population gives consequences of increased cattle waste. Cattle waste that is directly discharged into the untreated environment will contaminate the air, water and soil causing pollution. Farmers have been 
dumping and making cattle waste accumulate on their farms (Muis, 2015). Cattle farming is considered as one of the causes of $\mathrm{CO} 2$ emissions which lead to increased global warming. Efforts that can be made to minimize the increase in greenhouse gas emissions is by the pattern of integrated cattle-plant farming system. This system approach can provide optimal benefits can be achieved with the fulfillment of agricultural development criteria that combine economic interests, socio-cultural and environmental sustainability. This integration system is increasingly important given the availability of dry land for the development of livestock and feed sources is increasingly limited and expensive. The problem is whether the integration of cattle-crop farming benefits cattle farmers. The purpose of this research was to analyze the benefits of farming of cattle-crop integration.

\section{MATERIALS AND METHODS}

The research material was cattle population, cattle waste, feed, organic fertilizer (solid and liquid), Cattle population was expressed from the number of cattle in Regency of North Bolaang Mongondow and cattle ownership by group members. Cattle waste was seen from the many wastes produced by cattles every year. Cattle feed was a waste of rice that has been collected by members of the group. Organic fertilizer (solid and liquid) was the amount of organic fertilizer produced and sold by group members. The research method used was survey method. The location of the research was the district that has the largest population of cattle, namely Sangkub and Bintauna Districts determined by purposive sampling. Respondents numbered each district 30 farmers. Data analysis was descriptive, revenue analysis and proximate analysis.

\section{RESULTS AND DISCUSSION}

The population of cattle in North Bolaang Mongondow District is 14,690 heads can produce $176,280 \mathrm{~kg}$ of solid waste and 73,450 liters of liquid waste per day. This if not managed properly will result in greenhouse gas emissions. The results showed that the number of cattle ownership for 30 respondents in Sangkub District as much as 81 tails each day produces $972 \mathrm{~kg}$ of solid waste and $405 \mathrm{~kg}$ of liquid waste. While the ownership of cattles by 30 respondents in the District of Bintauna as much as 128 tails each day produces $1536 \mathrm{~kg}$ of solid waste and $640 \mathrm{~kg}$ of liquid waste. The respondents' cattle are left on agricultural land indicating environmental pollution.

Cattle waste that can not be internalized causing negative eksternlitas. Negative externality arising is shown from methane gas produced from cattle waste causing environmental pollution. Cattle waste can be internalized by cattle cultivated in cages so that the feces can be collected and processed into organic fertilizer. This organic fertilizer is used by farmers to reduce inorganic fertilizers are increasingly expensive and rare. Alternative solution of rising price of fertilizer according to Rachmadhani et al (2014) by using organic fertilizer to minimize the dependence of farmers on the use of inorganic fertilizers. Furthermore, food crop waste is used by farmers as cattle feed. The results showed that cattle business integrated with food crops has been done by several farmer groups in Regency of North Bolaang Mongondow. The group includes the Keong Mas group, which develops cattle using cages and the feed used is rice straw. Jamilah (2017) argues that one of the ways the government chooses to meet the cattle fattening program is through rice straw feeding technology. 
Cattle waste was processed by members into a solid and liquid organic fertilizer. The number of cattle that was caged as many as 24 tails. Liquid fertilizer produced was 25 liters per day which was sold at Rp 30000 per liter. Group members in this case earn an income of Rp750,000 per day, or Rp. 273.750.000 per year. Group members have also sold 10,000 kg of solid fertilizer per year at a price of Rp 1000 per $\mathrm{kg}$ so that the income earned was Rp 10,000,000 per year. This condition shows that the economic value of waste in the form of feces and urine increases, as well as a new source of income that affects the improvement of farmers' welfare. Samples of liquid fertilizer from the Keong Mas group have been analyzed at the Research Center and Industrial Standardization Manado. The nutrient elements analyzed from this research are the macro elements of Nitrogen (N), Potassium (K) and Phosphor (P) as Table 1.

Table 1. Result of Analysis of Liquid Fertilizer produced by Keong Mas Group

\begin{tabular}{|lll|}
\hline No. & Parameter & Value \\
\hline 1. & Nitrogen $(\%)$ & 0,1 \\
2. & Kalium $(\%)$ & 0,24 \\
3. & Phosphor $(\%)$ & 0,03 \\
4. & pH & 9,0 \\
\hline
\end{tabular}

Source: Analysis results of Industry Research and Standardization Center, Manado (2016)

Nitrogen elements according to the results of this study in accordance with Musnamar (2006) that is for the fertilizer derived from cattle dung $\mathrm{N}$ content element ranged from 0.1 to 0.96 . While the element of Potassium and Phorphor is lower than Musnamar (2006). Phosphorus element in manure is mostly derived from solid waste, while Nitrogen and Potassium comes from liquid waste. The content of $\mathrm{K}$ element in liquid manure is five times larger than solid waste. While the content of $\mathrm{N}$ in liquid feces is only 2-3 times greater than solid impurities.

The function of organic fertilizer was further socialized to other farmers in the research area. Organic fertilizer (manure) has been widely used in other areas in Indonesia for agricultural land both wetland and dry land. The goal is to improve soil fertility considering most of the agricultural land has been very lack of organic elements. Dry land is generally nutrient-poor, lack of water and less fertile so it is less productive to produce food sources and feed ingredients (Nurdiati et al, 2012). Compost fertilizer is used as an option in support of increased green mustard greens (Ohorella, 2012), tomato production (Pangaribuan et al., 2012). The productivity of feed crops according to Jasmani and Haryanto (2015), also can still be improved by providing organic fertilizer from cattle manure.

Management of crop and livestock integration systems increases farmers' income compared to non-integrated farming systems. This approach is recommended for farmers in the research area. Integrated farming system approach as a business done so that production costs can be reduced, unused agricultural land optimized with forage introduction, cattle as a source of labor (up to a certain age) and can contribute in saving the purchase of fertilizer. Research on integrated 
farming system has been done, among others Forero and Gonzalo (2013) which aims to explain the natural resources without negative impact on the environment. Integrated livestock management is less risky if managed efficiently and benefits are gained and achieved environmental health (Walia and Kaur, 2013). Integrated farming according to Wulandari (2014) is the right choice because of the limited ability of agricultural resources. Wahyuni (2015) argued that integrated agriculture is an alternative effort in order to improve the efficiency of cattle business in farmland. Furthermore, the Farming System Integration is an alternative to climate change mitigation (Munandar et al., 2015), and is often recommended as one of the most promoted solutions in terms of decreasing soil fertility and the loss in intensification system productivity (Ezeaku et al., 2015). Swarnam et al (2014) suggests an integrated approach to farming systems leads to improved household nutrition, income and employment creation. Development of cattle with the concept of integrated farming system is done by farmers who are members of a group. The reason is because according to Suprianto (2017) farmer group is one of the formal institutions that exist in the community.

\section{CONCLUSIONS}

Based on the result of the research, it can be concluded that integrated farming system, cattlecrop farming provides positive benefits for farmers in increasing income and minimize environmental pollution. Income solid organic fertilizer was Rp 31,250 per day per head. Suggestions submitted need socialization and assistance in the development of integrated cattle farming.

\section{ACKNOWLEDGMENT}

Thanks to DRPM DIKTI who has given opportunity to the author to get fund research through Research of Higher Educational Applications scheme.

\section{REFERENCES}

Ezeaku, I.E., B.N. Mbah., K.P. Baiyeri and E.C. Okechukwu. 2015. Integrated Crop-Livestock Farming System for Sustainable Agricultural Production in Nigeria. African Journal of Agricultural Research.p:4268-4274.

Forero, B and A. Gonzalo. 2013. Integrated Farming System to the Foothill-Regions of Colomba-Ariporo System (A.S). Journal Technology. Vol. 12 No.2.p:24-34.

Jamilah. 2017. Analysis of Income of Cattle Farmers of Aceh. Journal of Agrifo 2 (2) : 50-55.

Jasmani, S.N. and B. Haryanto. 2015. Improve the Productivity of Forage Feed to Support the Pasture Capacity of Buffalo in Kampar Regency, Riau (a suggestion for thinking). Pastura 4 (2): 95-99.

Munandar., F. Gustiar. Yakup., R. Hayati and A.I. Munawar. 2015. Crop-Cattle Integrated Farming System : an Alternative of Climatic Change Mitigation. Media Peternakan, Agustus 2015, 38 (2).p:95-103. 
Muis, J.M. 2015. Performance and Prospect of Development of Environmentally Friendly Beef Cattle in West Sumatera. Widyariset 18 (1) : 59-70.

Nurdiati, K., E. Handayanta and Lutojo. 2012. Production Efficiency of Beef Cattle in Dry Season in Small Farm of Dryland Farming Area of Gunung Kidul Regency. Tropical Animal Husbandry 1 (1) : 52-58.

Ohorella, Z. 2012. Influence of Dosage of Liquid Organic Fertilizer (POC) Cattle Manure on Growth and Production of Green Sawi Plant (Brassica sinensis L.). Agroferentri Journal VII (1): 43-49.

Pangaribuan, D.H., M. Yasir and N.K. Utami.2012. Impact of Bokashi from Livestock Dung In Reduction of Inorganic Fertilizer Use on Tomato Cultivation. J. agron. Indonesia 40 (3) : 204-210.

Rachmadhani, N.W., Koesriharti and M. Santoso. 2014. Effects of Organic Fertilizers and Inorganic Fertilizers on the Growth and Results of Phaseolus vulgaris L. Crops. Journal of Plant Production 2 (6) : 443-452.

Suprianto. 2016. Study of Artificial Insemination Technology Application in Efforts to Increase Productivity and Income of Cattle Livestock in Tasikmalaya Regency. Agribusiness Tribunal 1 (3) : 211-225.

Swarnam, T.P., A. Velmurugan., Z. George., N. Ravisankar., T.P. Sai., S.D. Ray and P. Srivastava. 2014. Integrated Farming System For Sustainable Livelihood in Tribal Areas of Nicobar Island, India. Journal of the Andaman Science Association 19 (1): 19-22.

Wahyuni, R. 2015. Structure of Mastery of Land Resources and Contribution of Beef Cattle to Farmers Household Income. Widyariset 18 (1) : 79-90.

Walia, S.S and N. Kaur. 2013. Integrated Farming System-An Ecofriendly Approach for Sustainable Agricultural Environment-A Review. Greener Journal of Agronomy Forestry and Horticulture. Vol. 1 (1). Sept 2013, p: 001-011. 